\title{
Mite Fauna (Arachnida: Acari) on Peach Cultivars in Presidente Prudente, São Paulo, Brazil
}

\author{
Sônia Maria Nalesso Marangoni Montes ${ }^{1}$, Adalton Raga ${ }^{2}$, Aparecida Conceição Boliani ${ }^{3}$, Jeferson Luiz de \\ Carvalho Mineiro ${ }^{2} \&$ Pedro César dos Santos ${ }^{3}$ \\ ${ }^{1}$ Sao Paulo State Agency of Technology Agribusiness-APTA, Regional Alta Sorocabana, Route Raposo Tavares \\ km 561, Box 298, Presidente Prudente, SP 19015-970, Brazil \\ ${ }^{2}$ APTA- Biological Institute, Avenue Heitor Penteado km 3, Box 70 Campinas, SP 13001-970, Brazil \\ ${ }^{3}$ Paulist State University-UNESP, Campus de Ilha Solteira, Avenue Brasil, 56, Ilha Solteira, SP 15385-000, \\ Brazil \\ Correspondence: Sônia Maria Nalesso Marangoni Montes, Sao Paulo State Agency of Technology \\ Agribusiness-APTA, Regional Alta Sorocabana Route Raposo Tavares km 561, Box 298, Presidente Prudente, \\ SP 19015-970, Brazil. Tel: 55-18-3222-0732. E-mail: soniamontes@apta.sp.gov.br
}

Received: March 15, 2012 Accepted: May 20, 2012 Online Published: September 1, 2012

doi: $10.5539 /$ jps.v1n2p173

URL: http://dx.doi.org/10.5539/jps.v1n2p173

Research supported by FAPESP (Processo nº5/55649-5)

\begin{abstract}
This study aimed to determine the mite diversity, population dynamics and to conduct a fauna analysis in plantations from four peach varieties established in the municipality of Presidente Prudente, SP, Brazil. The mite fauna from 'Jóia 4', 'Ouromel 3', 'Regis' and 'Rei da conserva' cultivars over the rootstock Okinawa were determined from December 2002 to February 2006. Samples composed by 72 leaves were collected fortnightly from upper, middle and lower third of each tree and four trees per cultivar. A total of 3,084 mites were recovered during the experiment, with the following distribution: 2,638 phytophagous, 373 predators and 73 of unknown feeding habit. The mites recovered were related to 18 species from 12 mite families. Aculus fockeui (Eriophyidae) occurred sporadically, not causing symptoms on the canopy. Euseius citrifoluis was the most abundant species among the Phytoseiidae, with predominance on cultivar 'Regis'.
\end{abstract}

Keywords: mite fauna, mite diversity, Prunus persica, stone fruits

\section{Introduction}

Fruit plants are infested by several species of insects and mites, which in some cases are considered pests. The knowledge about the mite diversity can determine the degree of importance of phytophagous species and also of predatory species, as a scientific basis for the integrated pest management in several crops (Vasconcelos et al., 2005). It can also help in the evaluation of the species potential to become pests or natural enemies, foreseeing their impact on the environment (Moraes \& Flechtmann, 2008).

The mite species are considered major pests on peaches, because their severe infestation destroys the superficial tissues of the leaves, which cause the loss of cell juice from the first tissue layers. This results in a color alteration, a yellowing or bronzing of the leaves, which provokes a qualitative and quantitative product reduction (Salles, 1998).

In Brazil, pest mite species that attack peach trees are the two-spotted spider mite (Tetranychus urticae Koch, 1836) (Tetranychidae), the red mites [Panonychus ulmi (Koch, 1836)] (Tetranychidae), and the peach silver mite [Aculus cornutus Banks, 1905)] (Eriophyidae) (Fletchmann, 1976; Santa-Cecília \& Souza, 1997). In Mexico, Eriophyes insidiousus Keifer \& Wilson, 1956 was recorded as a vector of a mosaic virus on peach trees (Oldfield \& Creamer, 1995).

In a study about the mite diversity in Rosaceae, in the municipality of Capão Bonito, São Paulo, Brazil, Baldo (2012) referred to the occurrence of the mites A. fockeui, T.urticae, Ricoseius loxocheles De Leon, 1965 and Euseius ho De Leon, 1965, The author also found a positive correlation between climatic conditions and the 
occurrence of phytophagous mites.

In another study on the population of predatory mites in peaches, especially the Phytoseiids family, Moraes et al. (1986) reported the occurrence of Euseius concordis (Chant, 1959), Iphiseiodes zuluagai Denmark \& Muma, 1972, Phytoseiulus macropilis (Banks, 1904) and Ricoseius loxocheles (De Leon, 1965). The predatory mites were considered effective in the biological control of phytophagous mites on roses. Their occurrence may be influenced by cultural management, which affects their establishment in the plants when released in the field (Monteiro, 2002).

The introduction of peach orchards in Presidente Prudente, in the western region of São Paulo State, aimed at the diversification of fruit cropping for the family-based farm. The knowledge about the mites' fauna in peach plantations in the western São Paulo State is very much incipient. The present research aimed to determine the mite diversity, the population dynamics and to conduct a fauna analysis in peaches orchards in western São Paulo State, with the purpose to subsidize pest management.

\section{Materials and Methods}

The survey was conducted in the municipality of Presidente Prudente, São Paulo, Brazil (UTM N 7,545,288.76 m, E 459,930.31 m and $424.29 \mathrm{~m}$ elevation) from December 2002 to February 2006. The orchards were established in 2001 with four peach cultivars: 'Joia 4', 'Ouromel 3', 'Regis' and 'Rei da conserva'. All cultivars require less than 100 chilling hours and are commonly used by commercial growers. The plant spacing was of $6.0 \times 3.0 \mathrm{~m}$. Information on mite fauna on those cultivars was not available in literature.

Except for the application of insecticides and miticides, other cultural practices employed in this study were those recommended for conventional peach trees (Pereira et al., 2002), such as artificial dormancy break performed with hydrogen cyanamide $(0.5 \%$ a.i. $)+$ oil $(1 \%)$, fruit thinning, fertilization, weed control (glyphosate, $0.5 \%$ a.i), green and dry pruning, and micro sprinkler irrigation.

In order to obtain the complete mite diversity, samplings were performed every fifteen days by collecting 12 leaves from the upper, middle and lower thirds of the plant (both internal and external parts). A total of 72 leaves were collected biweekly from each tree, from four trees per cultivar, was collected to guarantee a representative sample, but without compromising the plants development. The samples were placed into paper bags and kept in polystyrene boxes containing ice to decrease the mite activity. The mite extraction was performed at the Plant Health and Quality Laboratory at "APTA Alta Sorocabana”, in Presidente Prudente, SP, Brazil. To accomplish the extractions, the samples were placed individually in plastic containers and immersed for five minutes in a $70 \%$ alcohol solution and then stirred to displace the mites. The leaves were discarded and the solution was passed through a $0.038 \mathrm{~mm}$ sieve and the mites collected were transferred to $30 \mathrm{ml}$ capacity glass vials for later screening and identification. No leaves were sampled between May and August, due to plant natural defoliation. The mites collected were mounted in Hoyer's medium for identification, except the eriophids, which were mounted in modified Berlese medium (Krantz, 1978). A representative sample of the species found was deposited at the "Geraldo Calcagnolo Mites Reference Collection", at Laboratory of Acarology, Biological Institute, Campinas, SP.

A faunistic analysis and the characterization of mites' occurrence (accidental, accessory and constant) and dominance indices (accidental, accessory and dominant) were conducted to determine the mite species importance status (Palma, 1975).

\section{Results and Discussion}

Eighteen mite species were recorded in our survey, and the species were related to 12 distinct mite families (Table 1). A total of 3,084 mites were collected: 2,638 phytophagous, 373 predators, and 73 mites with unknown eating habits. 
Table 1. Mite species collected from peach leaves. Presidente Prudente, SP, Brazil. Dec/2002 to Feb/2006

\begin{tabular}{|c|c|c|c|}
\hline Order & Family & Genus/Species & Food habit \\
\hline \multirow[t]{2}{*}{ Astigmata } & Acaridae Latreille, 1802 & Tyrophagus sp. & Mycophagous \\
\hline & $\begin{array}{l}\text { Winterschmidtiidae Oudemans, } \\
1923\end{array}$ & Czenspinskia $\mathrm{sp.}$ & Mycophagous \\
\hline \multirow[t]{5}{*}{ Mesostigmata } & Phytoseiidae Berlese, 1913 & $\begin{array}{l}\text { Amblyseius herbicolus } \\
\text { (Chant, 1959) }\end{array}$ & Predator \\
\hline & & $\begin{array}{l}\text { Euseius citrifolius } \\
\text { Denmark \& Muma, } 1970\end{array}$ & Predator \\
\hline & & $\begin{array}{l}\text { Euseius concordis } \\
\text { (Chant, 1959) }\end{array}$ & Predator \\
\hline & & $\begin{array}{l}\text { Iphiseiodes zuluagai } \\
\text { Denmark \& Muma, } 1972\end{array}$ & Predator \\
\hline & & & Predator \\
\hline \multirow[t]{12}{*}{ Prostigmata } & Bdellidae Dugès, 1834 & Spinibdella sp. & Predator \\
\hline & Diptilomiopidae Keifer, 1944 & Catarhynus sp. & Phytophagous \\
\hline & Cheyletidae Leach, 1815 & Grallacheles sp. & Predator \\
\hline & Eriophyidae Nalepa, 1898 & $\begin{array}{l}\text { Aculus fockeui } \\
\text { (Nalepa \& Trouessart, 1891) }\end{array}$ & Phytophagous \\
\hline & Tarsonemidae Kramer, 1877 & Fungitarsonemus sp. & Phytophagous \\
\hline & & Tarsonemus sp. & Phytophagous \\
\hline & Tenuipalpidae Berlese, 1913 & $\begin{array}{l}\text { Brevipalpus phoenicis } \\
\text { (Geijskes, 1939) }\end{array}$ & Phytophagous \\
\hline & Tetranychidae Donnadieu, 1875 & $\begin{array}{l}\text { Mononychellus planki } \\
\text { (McGregor, 1950) }\end{array}$ & Phytophagous \\
\hline & & Oligonychus sp. & Phytophagous \\
\hline & & $\begin{array}{l}\text { Tetranychus urticae } \\
\text { Koch, } 1836\end{array}$ & Phytophagous \\
\hline & Tydeidae Kramer, 1877 & Lorryia sp. & Mycophagous \\
\hline & Iolinidae & Homeopronematus sp. & Mycophagous \\
\hline
\end{tabular}

The occurrence of the phytophagous species Aculus fockeui (Nalepa \& Trouessart, 1891) (Eriophyidae) was registered in all cultivars, with high populations captured in December 2002. In Rei da conserva cultivar, $A$. fockeui represented $63.4 \%$ of total individuals $(1,572)$. In contrast, only $4.8 \%$ of the mites recovered from Ouromel 3 cultivar (120) were A. fockeui was (Table 2). Another eriophyid, Catarhynus sp. was detected in very low number (Table 1). A. fockeui is reported in several regions around the world as the major peach-associated mite (Kondo \& Hiramatsu, 1999; Ferreira \& Carmona, 1997; Kunugi et al., 1993), causing decrease in fruit weight, sugar content (Kunugi et al., 1993; Kondo \& Hiramatsu, 1999), defoliation and reduced plant vigor, and resulting in poor fruit quality in subsequent years (Kondo \& Hiramatsu, 1999). Contradictorily observations made elsewhere in the world, in the present study there were no detected visual symptoms associated with the occurrence of this mite. Eichelberger et al. (2011) also reported that A. fockeui has little relevance in peach orchards in Rio Grande do Sul.

Three species of Tetranychidae were identified (Table 2). Mononychellus planki (McGregor, 1950) were found in larger quantities than other spider mites. In Rei da conserva cultivar, $61.4 \%$ of total mites sampled were $M$. planki. Brevipalpus phoenicis (Geijskes, 1939) were recovered mainly on 'Regis' and 'Jóia 4' cultivars (68.80\% 
and $25.50 \%$ respectively).

Table 2. Percentage distribution of mite species occurring on four peach cultivars. Presidente Prudente, SP, Brazil. Dec/2002 to Feb/2006

\begin{tabular}{lcccc}
\hline \multicolumn{1}{c}{ Species } & \multicolumn{4}{c}{ \% occurrence on peach cultivars } \\
& Jóia 4 & Ouromel 3 & Régis & Rei da conserva \\
\hline Phytophagous & & & & \\
Aculus fockeui & $84.60 \%$ & $79.74 \%$ & $44.78 \%$ & $89.17 \%$ \\
Mononychellus planki & $0.14 \%$ & $10.93 \%$ & $1.65 \%$ & $3.52 \%$ \\
Tetranychus urticae & $1.63 \%$ & $2.65 \%$ & $3.57 \%$ & $0.79 \%$ \\
Brevipalpus phoenicis & $0.54 \%$ & $0.33 \%$ & $3.57 \%$ & $0.11 \%$ \\
Oligonychus sp. & $0.14 \%$ & $0.00 \%$ & $0.00 \%$ & $0.00 \%$ \\
Homeopronematus sp. & $1.08 \%$ & $0.99 \%$ & $0.55 \%$ & $0.28 \%$ \\
Predators & & & & \\
Euseius citrifolius & $10.57 \%$ & $40.07 \%$ & $30.22 \%$ & $5.10 \%$ \\
Euseius concordis & $0.95 \%$ & $3.31 \%$ & $7.14 \%$ & $0.34 \%$ \\
Iphiseiodes zuluagai & $0.00 \%$ & $0.00 \%$ & $0.82 \%$ & $0.00 \%$ \\
Unknown food habits & & & & \\
Lorryia sp. & $0.00 \%$ & $0.66 \%$ & $0.27 \%$ & $0.06 \%$ \\
Tyrophagus sp. & $0.14 \%$ & $4.30 \%$ & $1.10 \%$ & $0.57 \%$ \\
Czenspinskia sp. & $0.27 \%$ & $33.00 \%$ & $3.57 \%$ & $0.06 \%$ \\
\hline
\end{tabular}

Montes et al. $(2010,2011)$ reported a greater diversity of phytophagous mites on peach cultivars Talismã, Doçura 2, Dourado 2, Tropical, Aurora 1 and Aurora 2, planted in Presidente Prudente: Diptilomiopidae, Eriophyidae, Tarsonemidae, Tenuipalpidae and Tetranychidae. The authors also reported the occurrences of predator mites from the Ascidae, Phytoseiidae, Bdellidae, Cheyletidae and Erythraeidae families. Constrasting results were obtained in Pelotas and Bento Gonçalves counties, RS, where P. ulmi and T. urticae were the most abundant species detected on three peach cultivars in conventional and integrated management systems (Cunha et al., 2010).

In Italy, Castagnoli \& Nannelli (1987) found high densities of $A$. fockeui in a peach orchard, but these authors did not find apparent damage, probably due to biological control by predators mites. However, according to Ashihara et al. (2004), injuries on the peach leaves caused by A. fockeui reduce the sugar content of the fruit, promoting intense leaf fall just after harvesting. The resurgence of $A$. fockeui registered there was probably due to the negative effects of synthetic phyrethroid on predator mites.

In Toscana (Italy), 20 mite species have been reported in peach trees, especially the phytophagous $A$. fockeui, Orthotydeus kochi (Oudemans, 1929), Pronematus ubiquitus (McGregor, 1923) and the predator Amblyseius andersoni (Chant, 1957), A. stipulates (Athias-Henriot, 1960) and Agistemus collyerae Gonzales-Rodrigues, 1963. Although A. fockeui occurred at high densities (200 mites/leaf), there were no signs of damage, probably due to the action of predators (Castagnoli \& Nanelli, 1987). In India, Putatunda et al. (2000) reported the occurrence of 90 species of mites in various fruits, including peaches, with the dominance of Tenuipalpidae , Tetranychidae and Phytoseiidae.

Among the predators collected in our study, Cheyletidae and Phytoseiidae species were reported (Table 1). The highest species richness and numbers of individuals registered was from the Phytoseiidae family.

The population of predators, specially E. citrifolius, may explain the low population levels of phytophagous mites. On Regis cultivar, which had the lowest incidence (6.6\%) among the four cultivars, the highest population of I. zuluagai (100\%) and E. concordis $(53.10 \%)$ was recovered (Table 3$)$. 
Table 3. Percentage of major mites occurred on peach cultivars in relation to the total collected. Presidente Prudente, SP, Brazil. Dec/2002 to Feb/2006

\begin{tabular}{cccccc}
\hline \multirow{2}{*}{ Species } & \multicolumn{5}{c}{$\begin{array}{c}\% \text { of mites on peach cultivars in relation to the total collected in } \\
\text { all four cultivars }\end{array}$} \\
\cline { 3 - 6 } & $\begin{array}{c}\text { Total of mites } \\
\text { collected }\left(\mathrm{n}^{\circ}\right)\end{array}$ & Jóia 4 & Ouromel 3 & Régis & Rei of conserva \\
\hline Phytophagous & & & & & \\
Aculus fockeui & 2479 & $25.20 \%$ & $4.80 \%$ & $6.60 \%$ & $63.40 \%$ \\
Mononychelus planki & 101 & $0.99 \%$ & $31.70 \%$ & $5.90 \%$ & $61.40 \%$ \\
Tetranychus urticae & 35 & $34.30 \%$ & $14.30 \%$ & $17.10 \%$ & $34.30 \%$ \\
Brevipalpus phoenicis & 16 & $25.00 \%$ & $6.30 \%$ & $68.80 \%$ & $0.00 \%$ \\
Oligonychus sp. & 1 & $100.00 \%$ & $0.00 \%$ & $0.00 \%$ & $0.00 \%$ \\
\hline Predators & & & & & \\
Iphyseiodes zuluagai & 3 & $0.00 \%$ & $0.00 \%$ & $100.00 \%$ & $0.00 \%$ \\
Euseius citrifolius & 317 & $19.90 \%$ & $29.30 \%$ & $26.80 \%$ & $24.00 \%$ \\
Euseius concordis & 49 & $14.30 \%$ & $20.40 \%$ & $53.10 \%$ & $12.20 \%$ \\
\hline
\end{tabular}

(n) - number

In the area of the present study, earlier occupied by citrus orchards, Sato et al. (1994) identified six species of phytoseiid mites during 1990/1991 growing season, especially I. zuluagai, E. citrifolius and E. concordis. In the current study, E. citrifolius, E. concordis and I. zuluagai occurred with a frequency of $10.27 \%, 1.59 \%$ and $0.10 \%$ of the total mites collected. In Pelotas and Bento Gonçalves, RS, Cunha et al. (2010) found six Phytoseiidae and one Stigmaiidae species, with dominance of Neoseiulus californicus (McGregor, 1954) and Euseius brazilii (El-Benhawy, 1975). Ferla and Moraes (2000) recorded the occurrence of Cunaxoides sp., E. alatus DeLeon, 1966 , E. brazilii , E. citrifolius and E. concordis on peach trees (RS).

In Italy, Castagnoli \& Nannelli (1987), reported the predators $O$. kochi and P. ubiquitus, (Tydeidae), A. andersoni and E. stipulatus (Phytoseiidae) and A. collyerae. (Stigmaeidae) on peaches.

Table 4. Faunistic analysis of the main phytophagous and predator mites occurring on peach cultivars, Presidente Prudente, SP, Brazil. Dec/2002 to Feb/2006

\begin{tabular}{lcccccccc}
\hline \multirow{2}{*}{ Species } & \multicolumn{2}{c}{ Jóia 4 } & \multicolumn{2}{c}{ Ouromel 3 } & \multicolumn{2}{c}{ Régis } & \multicolumn{2}{c}{ Rei da conserva } \\
& $\mathrm{N}$ & Status & $\mathrm{N}$ & Status & $\mathrm{N}$ & Status & $\mathrm{N}$ & Status \\
\hline Phytophagous & & & & & & & & \\
Aculus fockeui & 624 & $\mathrm{I}$ & 120 & $\mathrm{I}$ & 163 & $\mathrm{I}$ & 1572 & $\mathrm{C}$ \\
Mononychellus planki & 1 & $\mathrm{R}$ & 32 & $\mathrm{I}$ & 6 & $\mathrm{R}$ & 62 & $\mathrm{I}$ \\
Tetranychus urticae & 12 & $\mathrm{R}$ & 5 & $\mathrm{R}$ & 6 & $\mathrm{R}$ & 12 & $\mathrm{C}$ \\
Brevipalpus phoenicis & 4 & $\mathrm{R}$ & 1 & $\mathrm{R}$ & 11 & $\mathrm{I}$ &. &. \\
Predators & & & & & & & & \\
Euseius citrifolius & 63 & $\mathrm{C}$ & 93 & $\mathrm{C}$ & 85 & $\mathrm{C}$ & 76 & $\mathrm{I}$ \\
Euseius concordis & 7 & $\mathrm{R}$ & 10 & $\mathrm{I}$ & 26 & $\mathrm{I}$ & 6 & $\mathrm{R}$ \\
\hline
\end{tabular}

$\mathrm{N}$ : total of individuals

Status of species (C): common; (I): intermediate; (R): rare

The highest species richness of phytophagous mites was observed in Jóia 4 cultivars (six species), followed by 'Ouromel 3', 'Rei da conserva' and 'Regis', with five species each. B. phoenicis showed a preference for 'Regis' 
cultivar (Table 3).

A. fockeui was constant in Rei da conserva cultivar and intermediate in the remaining cultivars (Table 4), representing more than $80 \%$ of the total mites. The occurrence of $M$. planki (the most abundant species in the beginning of the study in December 2002) became intermediate for all cultivars along the study, while the occurrence of T. urticae was constant for Rei da conserva cultivar (Table 4).

In Portugal, Ferreira \& Carmona (1997) recorded 27 mite species: seven phytophagous, eleven predators and nine designated as indifferent. The most representative phytophagous populations were $A$. fockeui $(41.6 \%)$ and Tetranychus cinnabarinus (Boisduval, 1987) (20\%), which in contrast with our study observations, it caused silvering of the foliage by the first species, and tanning, by the second species, respectively.

Studies about phytophagous and predator mites population on soil cover plants should be accomplished to clarify the role of other plant species as alternative hosts, as well as essays to determine pesticide with little effect on predator mites, in order to support the management of mites incidence on peach.

\section{Conclusion}

Eighteen mite species belonging to 12 families were detected on peach cultivars in Presidente Prudente, western Sao Paulo State, with the predominance of the phytophagous species A. fockeui and the predator E. citrifolius.

\section{References}

Ashihara, W., Kondo, A., Shibao, M., Tanaka, H., Hiehata, K., \& Izumi, K. (2004). Ecology and control of eriophyid mites injurious to fruit trees in Japan. Japan Agricultural Research Quaterly, 38(1), 31- 41.

Baldo, F. B. (2012). Diversidade e dinâmica populacional de ácaros em Rosaceae na região sudoeste do estado de São Paulo. Dissertação de Mestrado, Instituto Biológico- APTA, p.83.

Castagnoli, M., \& Nannelli, R. (1987). Further observations on populations trend of mites in an experimental peach meadow orchard in central Italy. Redia, 70(2), 121-133.

Cunha, U. S. da, Moraes, J. J. de, Nava, D. E., Botton, M., \& Bertin, A. (2010). Mite (Acari) diversity on peach trees in different production systems in the State of Rio Grande do Sul, Brazil. In: INTERNATIONAL CONGRESS OF ACAROLOGY, 13, Recife. Anais. p.64.

Eichelberger, C. R., Flutuação populacional de ácaros na cultura do pessegueiro [Prunus persica (L.) Batsch ] em plantas associadas (2011). Revista Brasileira de Fruticultura, 33(3), 765-773. http://dx.doi.org/10.1590/S0100-29452011005000102

Ferreira, M. A., \& Carmona, M. M. (1997). Acarofauna do pessegueiro em Portugal. Boletin de Sanidad Vegetal, 23(3), 473-478.

Flechtmann, C. H. W. (1976). Ácaros de importância agrícola. São Paulo, Brasil: Nobel.

Ferla, N. J., \& Moraes, G. J. de. (2002). Ácaros predadores (Acari) em plantas nativas e cultivadas do Estado do Rio Grande do Sul, Brasil. Revista Brasileira de Zoologia, 19(2), 1011-1031. http://dx.doi.org/10.1590/S0101-8175200200040006

Krantz, G. W. (1978). A Manual of Acarology. (2nd ed.). Oregon State University, Inc. Corvallis.

Kondo, A., \& Hiramatsu, T. (1999). Analysis of peach tree damage caused by each silver mite, Aculus fockeui (Nalepa \& Trouessart). Japanese Journal of Applied Entomology and Zoology, 43(4), 189-193.

Kunugi, Y., Terai, Y., \& Kato, S. (1993). Seasonal occurrence of peach silver mite, Aculus fockeui (Nalepa \& Trouessart), on peach levels and their effects on fruit development. Proceedings of the Kanto Tosan Plant Protection Society, 40(2), 269-271.

Moraes, G. J., McMurthy, J. A., \& Denmark, H. A. (1986). A catalog of the mite family Phytoseiidae: References to taxonomy, synonymy, distribution and habitat. Brasília, Brazil: EMBRAPA-DDT.

Monteiro, L. B. (2002). Manejo integrado de pragas em macieiras no Rio Grande do Sul: Uso de Neoseiulus californicus para o controle de Panonychus ulmi. Revista Brasileira de Fruticultura, 24(2), 395-405. http://dx.doi.org/10.1590/S0100-29452009000200011

Montes, S. M. N. M., Raga, A., Boliani, A. C., Mineiro, J. L. C., \& Santos, P. C. dos. (2010). Composição acarina em diferentes cultivares de pessegueiros [(Prunus persica (L.)] em Presidente Prudente, Estado de São Paulo. Revista Brasileira de Fruticultura, 32(2), 414-422. http://dx.doi.org/10.1590/S0100-2945210005000050 
Montes, S. M. N. M., Raga, A., Boliani, A. C., Mineiro, J. L. C., \& Santos, P. C. dos. (2011). Effect of fungicides on the mite fauna of Prunus persica L. cultivars in Presidente Prudente, SP, Brazil. Journal Plant Protection Research , 51(3), 285-293. http://dx.doi.org/10.2478/v10045-011-0047-3

Moraes, G. J., \& Flechtmann, C. W. H. (2008). Manual de acarologia: Acarologia básica e ácaros de plantas cultivadas no Brasil. Ribeirão Preto: Holos.

Oldfield, G. N., \& Creamer, R. (1995). Incidence and distribution of Peach Mosaic and its vector, Eriophyes insidiosus (Acari: Eriophyidae) in Mexico. Plant disease, 79(2), $186-189$. http://dx.doi.org/10.1094/PD-79-0186

Palma, S. (1975). Contribución al estudio de los sinoforos encontrados frente a la costa de Valparaiso. Aspectos ecologicos. In SIMPOSIO LATINOAMERICANO OCEANOGRAFIA BIOLÓGICA, 2. Venezuela: Universidade d'Oriente. 119-133.

Pereira, F. M., Nachtigal, J. C., \& Roberto, S. R. (2002). Tecnologia para a cultura do pessegueiro em regiões tropicais e subtropicais. Jaboticabal: FUNEP.

Putatunda, B. N., Mathur, R. B., \& Mathur, S. (2002). Mites associates with some fruit trees in Hisar, Haryana. Journal of Agriculture Research, Indian, 36(2), 88-95.

Salles, L. A. B. (1998). Principais pragas e seu controle. In MC. A. B. Medeiros. \& M.C. Raseira (Eds.). A cultura do pessegueiro (pp. 205-242). Brasília: SPI.

Santa-Cecília, L. V. C., \& Souza, J. C. (1997). Pessegueiro e ameixeira: Reconhecimento e manejo das principais pragas do pessegueiro. Informe Agropecuário, 18(189), 56-62.

Sato, M. E., Raga, A., Cerávolo, L. C., Rossi, A. C., \& Potenza, M. R. (1994). Ácaros predadores em pomar cítrico de Presidente Prudente, Estado de São Paulo. Anais da Sociedade Entomológica do Brasil, 23(3), 435-441. http://dx.doi.org/10.590/S0301-80592000000100012

Vasconcelos, G. J. N. de., Silva, F. R. da, Barbosa, D. G. F., Gondim Júnior, M. G. C., \& Moraes, G. J. de. (2005). Ocorrência de Eriophyoidea, Tenuipalpidae, Tarsonemidae e Tukerellidae (Acari) em fruteiras no estado de Pernambuco, Brasil. Caating, 18(2), 98-104. 